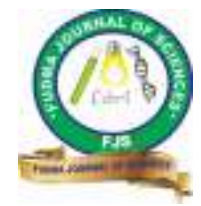

FUDMA Journal of Sciences (FJS)

ISSN online: $2616-1370$

ISSN print: 2645 - 2944

Vol. 4 No. 3, September, 2020, pp $170-177$

DOI: https://doi.org/10.33003/fjs-2020-0403-267

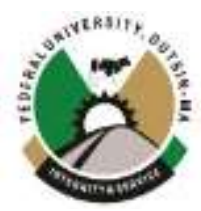

\title{
COMPARATIVE ANALYSIS OF THE MINERAL COMPOSITIONS OF HONEY SAMPLES COLLECTED FROM THE THREE SENATORIAL DISTRICTS OF KANO STATE, NIGERIA
}

\author{
${ }^{* 1}$ Datti Y., ${ }^{2}$ Ahmad, U. U. and ${ }^{3}$ Hafsat, N. \\ ${ }^{1}$ Department of Chemistry, Yusuf Maitama Sule University, Kano State, Nigeria. \\ ${ }^{2}$ Department of Science Laboratory Technology, School of Technology, Kano State, Nigeria \\ ${ }^{3}$ Shehu Idris College of Health Science and Technology Makarfi, Kaduna State, Nigeria \\ *Corresponding Author's Email: yaudatti@gmail.com
}

\begin{abstract}
Honey, the unique, natural, liquid sweetening agent is produced by honey bees from the nectar of plants or from honeydew. Honey is also known to have many medicinal applications including antimicrobial, antibacterial, antifungal, anti-inflammatory and antioxidant activities. The composition of honey may vary due to geographical location, environmental and climatic conditions, plant species, as well as the methods employed during collection and storage of the honey. Honey contains different types of proteins, hormones, enzymes, vitamins, minerals, yeast, as well as organic acids, and principally sugars. This study was conducted in order to analyze and compare the mineral contents of the honey samples collected at the three senatorial districts of Kano state, with three honey samples collected from two local governments each from the three Senatorial Districts of Kano State, Nigeria. The mineral compositions of all the honey samples were determined using flame photometer and atomic absorption spectrophotometer. All the honey samples analyzed were found to be rich in $\mathrm{K}(247.49$ to $251.73 \mu \mathrm{g} / \mathrm{g}$ ); $\mathrm{Na}$ (137.16 to $147.53 \mu \mathrm{g} / \mathrm{g}$ ); $\mathrm{Ca}$ (188.57 to $221.32 \mu \mathrm{g} / \mathrm{g}$ ); $\mathrm{Mg}$ (76.49 to 78.83 $\mu \mathrm{g} / \mathrm{g})$ and $\mathrm{Zn}(31.15$ to $48.92 \mu \mathrm{g} / \mathrm{g})$, while $\mathrm{Fe}$ (6.84 to $14.27 \mu \mathrm{g} / \mathrm{g}) ; \mathrm{Mn}(0.08$ to $0.13 \mu \mathrm{g} / \mathrm{g}) ; \mathrm{Cu}$ (0.12 to 0.25 $\mu \mathrm{g} / \mathrm{g}$ ); $\mathrm{Ni}(0.98$ to $1.27 \mu \mathrm{g} / \mathrm{g}$ ) and $\mathrm{Pb}$ (not detectable to $0.0002 \mu \mathrm{g} / \mathrm{g}$ ) were found in smaller concentrations, The mineral compositions of all the honey samples were found to meet the international honey standards, and are therefore suitable for human consumption.
\end{abstract}

Keywords: Honey, mineral composition, medicinal application, senatorial districts.

\section{NTRODUCTION}

Honey is a unique, natural, liquid sweetening agent produced by honey bees (Apis mellifera) from the nectar of plants or from honeydew (Codex Alimentarius 2002; El-Bialee and Sorour 2011; Adugna et al., 2020). The composition of honey may vary due to geographical location, environmental and climatic conditions, plant species, as well as the methods employed during collection and storage of the honey (De Rodriguez et al., 2004; Kucuk et al., 2007; Laleh et al., 2013). However, generally honey contains different types of proteins, hormones, enzymes, vitamins, minerals, yeast, some heavy metals, as well as organic acids, and principally sugars (Hernandez et al., 2005; Kujawski and Namiesnik 2008; Pohl 2009; Wang and Li 2011; Adugna et al., 2020). The organic acids are mainly pyruvic, lactic and formic (Bogdanov 2009). The physicochemical parameters of honeys have been strictly defined and serve as quality indicators of individual honeys, with honeys of same variety having similar physicochemical parameters (Juszczak et al., 2009; Laleh 2013). Numerous researches have been conducted (Adebiyi et al., 2004; Rodriguez et al., 2004; Downey et al., 2005; Finola et al., 2007; Al et al., 2009; Juszczak et al., 2009; Ajlouni and Sujirapinyokul 2010; Abel and Adedoyin 2011; Laleh et al., 2013; Adeniyi et al., 2014; Boussaid et al., 2018; Adugna 2020) and many are still on-going, to determine the physicochemical properties of honeys.

Even though honey is widely used as food and as sweetening agent, it is also known to have many medicinal applications (Farida et al., 2014). Honey was reported to exhibit healing powers in the treatments of many disorders (Gulfraz et al.,
2010), with its antimicrobial, antibacterial, antifungal, antiinflammatory and antioxidant activities also reported (Omafuvbe and Akanbi 2009; Gomes et al., 2010; Gulfraz et al., 2010; Kumar et al., 2013).

Knowledge of the nutritional value and the possible toxicological constituents of all local food substances is of utmost importance (Nnam 2003), as this will help eliminate all dietary problems associate with the deficiencies of such food substances (SCN 2006). Thus, the present study was conducted to analyze and compare the mineral contents of the honey samples collected the three Senatorial Districts of Kano state.

\section{MATERIALS AND METHODS}

\section{Samples Collection}

Three honey samples were collected from two local governments each from the three Senatorial Districts of Kano state, Nigeria. The samples were stored in clean airtight bottles at an ambient temperature to avoid growth of microorganisms as well as absorption of moisture (Gulfraz et al., 2010; Laleh et al., 2013). The samples were collected from the following areas: Kano Central (Dawakin Kudu and Ungogo); Kano South (Bebeji and Ajingi); Kano North (Gwarzo and Makoda), and all the honey samples were collected directly from the honey bee farmers.

\section{Determination of Mineral Composition}

To carry out the digestion of the honey samples, $1 \mathrm{~g}$ of each of the honey samples was weighed, homogenized, and placed in a conical flask. Concentrated nitric acid $(8 \mathrm{mls})$ and hydrogen peroxide $(4 \mathrm{mls})$ were added on to the sample in the conical 
flask. The mixture was then placed on a water-bath and heated for $4 \mathrm{hr}$ to dryness, and then the flask was removed and cooled to room temperature. De-ionized water was then added to the sample in order to dissolve the dried substance (Tuzen et al., 2007; Adugna et al., 2020). The content was then filtered using Whatman no. 42 filter paper into a clean volumetric flask (10 mls), and subsequently the solution was made up to the volume with the de-ionized water. Using the same procedure, the reagent blank was prepared using the reagents, concentrated nitric acid and hydrogen peroxide, and then treating them in similar way as the samples (Tuzen et al., 2007; Adugna et al., 2020).

The mineral compositions of all the honey samples were determined using flame photometer (Model: Buck VGP 410) and atomic absorption spectrophotometer (Model: Bulk VGP 210). Potassium $(\mathrm{K})$ and sodium $(\mathrm{Na})$, calcium $(\mathrm{Ca})$, magnesium $(\mathrm{Mg})$, zinc $(\mathrm{Zn})$ and iron $(\mathrm{Fe})$ were analyzed by flame atomic absorption spectrometry (FAAS), while manganese (Mn), copper $(\mathrm{Cu})$, nickel $(\mathrm{Ni})$ and lead $(\mathrm{Pb})$ were analyzed by atomic absorption spectrometry (AAS) as reported by Mohammed et al., (2014) and Oyeyemi et al., (2015).

\section{RESULTS AND DISCUSSION \\ Results}

The mineral compositions of all the honey samples analyzed are presented in Table 1 below.

Table 1: Mineral Compositions of the Honey Samples

\begin{tabular}{|c|c|c|c|c|c|c|c|c|c|c|}
\hline Sample & $\begin{array}{l}\mathrm{K} \\
\mu \mathrm{g} / \mathrm{g}\end{array}$ & $\begin{array}{l}\mathrm{Na} \\
\mu \mathrm{g} / \mathrm{g}\end{array}$ & $\begin{array}{l}\mathrm{Ca} \\
\mu \mathrm{g} / \mathrm{g}\end{array}$ & $\begin{array}{l}\mathrm{Mg} \\
\mu \mathrm{g} / \mathrm{g}\end{array}$ & $\begin{array}{l}\mathrm{Zn} \\
\mu \mathrm{g} / \mathrm{g}\end{array}$ & $\begin{array}{l}\mathrm{Fe} \\
\mu \mathrm{g} / \mathrm{g}\end{array}$ & $\begin{array}{l}\text { Mn } \\
\mu \mathrm{g} / \mathrm{g}\end{array}$ & $\begin{array}{l}\mathrm{Cu} \\
\mu \mathrm{g} / \mathrm{g}\end{array}$ & $\begin{array}{l}\mathrm{Ni} \\
\mu \mathrm{g} / \mathrm{g}\end{array}$ & $\begin{array}{l}\mathrm{Pb} \\
\mu \mathrm{g} / \mathrm{g}\end{array}$ \\
\hline $\mathrm{KC} \mathrm{A}$ & 251.73 & 146.94 & 188.57 & 76.49 & 33.37 & 6.84 & 0.08 & 0.13 & 0.98 & 0.0002 \\
\hline $\mathrm{KC} \mathrm{B}$ & 249.91 & 147.53 & 193.68 & 78.21 & 31.15 & 8.11 & 0.11 & 0.16 & 1.27 & 0.0001 \\
\hline $\mathrm{KS} \mathrm{A}$ & 247.49 & 139.51 & 217.09 & 77.63 & 41.07 & 12.36 & 0.09 & 0.21 & 1.09 & 0.0001 \\
\hline KS B & 248.12 & 140.29 & 221.32 & 76.59 & 39.79 & 14.27 & 0.12 & 0.25 & 1.06 & ND \\
\hline KN A & 249.37 & 137.16 & 197.95 & 77.18 & 37.34 & 11.79 & 0.12 & 0.12 & 1.21 & ND \\
\hline KN B & 248.76 & 138.93 & 199.87 & 78.83 & 48.92 & 9.85 & 0.13 & 0.13 & 1.25 & ND \\
\hline WHO/ & 3500 to & 1500 & 300 & 26 to 260 & 350 & 13.7 & 5.50 & 300 & 5.00 & $0.50 \mu \mathrm{g} / \mathrm{g}$ \\
\hline FAO & $\begin{array}{l}4700 \\
\mathrm{mg} / \text { day }\end{array}$ & $\begin{array}{l}2300 \\
\mathrm{mg} / \mathrm{day}\end{array}$ & $\begin{array}{l}1300 \\
\mathrm{mg} / \text { day }\end{array}$ & $\mathrm{mg} /$ day & $\mu \mathrm{g} / \mathrm{g}$ & $\begin{array}{l}20.5 \\
\mathrm{mg} / \text { day }\end{array}$ & $\mu \mathrm{g} / \mathrm{g}$ & $\mu \mathrm{g} / \mathrm{g}$ & $\mu \mathrm{g} / \mathrm{g}$ & \\
\hline
\end{tabular}

Key: KC A = Dawakin Kudu; KC B = Ungogo; KS A = Bebeji; KS B = Ajingi; KN A = Gwarzo; KN B = Makoda; ND = Not Detected

\section{DISCUSSION}

The differences in the minerals concentrations in the honey samples can be attributed to variations in the botanical and geographical origins of the honeys, (Rasheed and Soltan 2004), as well as environmental pollution, and the differences in beekeeping practices and processing (Pohl 2009).

Potassium is the third most abundant mineral in the body and helps the body regulate fluid, send nerve signals, regulate muscle contractions, maintain a regular heartbeat (Aburto et al., 2013) and also helps in preventing kidney stones (Kanu et al., 2013). Potassium is also known to help in reducing reduces blood pressure, protects against stroke and prevents osteoporosis (Raman 2017). The concentrations of potassium in all the honey samples analyzed in this study fall between $247.49 \mu \mathrm{g} / \mathrm{g}$ (Bebeji honey) to $251.73 \mu \mathrm{g} / \mathrm{g}$ (Dawakin Kudu honey), and these results are in agreement with similar results reported by Pisani et al., (2008); Adeniyi et al., (2014); Mohammad et al., (2014) and Nwoko et al., (2017). However, the results are higher than those reported by Kumar et al., (2013); Oyeyemi et al., (2013); Ndife et al., (2014); Ahed and Khalid (2017), while on the other hand, Conti (2000); Downey et al., (2005) and Terrab et al., (2005) have reported much higher results than that of the present study. Sodium is an essential electrolyte that helps maintain the balance of water in and around our cells. It is important for proper muscle and nerve function, and also helps maintain stable blood pressure levels, with its deficiency or low levels in our bodies requiring medical emergency, as it can cause irritability, weakness, fatigue, loss of consciousness, seizures, coma, etc. (Kim 2019). The concentrations of sodium in the honey samples analyzed in the present study were found to range from 137.16 $\mu \mathrm{g} / \mathrm{g}$ (Gwarzo honey) to $147.53 \mu \mathrm{g} / \mathrm{g}$ (Ungogo honey), and these results are higher than that reported by Kumar et al., (2013);
Adeniyi et al., (2014); Mohammad et al., (2014); Ndife et al., (2014); Saeed et al., (2014); Ahed and Khalid (2017) and Nwoko et al., (2017), with the discrepancy possibly attributed to the geographical variation in the location of the honey sources (Conti 2000). However, the results compare with similar reports by Adebiyi et al., (2004); Saxena et al., (2010); Vanhanen et al., (2011); Oyeyemi et al., (2013); Boussaid et al., (2018); Ezeh et al., (2018).

Calcium is the most important and most plentiful mineral found in the human body that forms and maintains healthy teeth and bones, as well as prevents osteoporosis (Turan et al., 2003; Piste et al., 2013). Calcium also helps in clotting of blood, sending and receiving nerve signals, squeezing and relaxing muscles, and helps in keeping a normal heartbeat (Piste et al., 2013). Calcium is the second most abundant mineral in honey (Adebiyi et al., 2004; Boussaid et al., 2014; Ahed and Khalid (2017), and this supports the present study that recorded the concentration of calcium second to that of potassium. All the samples analyzed in this study recorded a high calcium content ranging from 188.57 $\mu \mathrm{g} / \mathrm{g}$ (Dawakin Kudu honey) to $221.32 \mu \mathrm{g} / \mathrm{g}$ (Ajingi honey), with these results similar to that reported by Adebiyi et al., (2004); Agbagwa et al. (2011); Kumar et al., (2013); Oyeyemi et al., (2015). However, the results are much higher than that reported by Conti (2000); Adeniyi et al., (2014); Ndife et al., (2014); Ahed and Khalid (2017); Nwoko et al., (2017), but lower than that reported by Gulfaraz et al., (2010).

Magnesium is another abundant mineral in the body that is naturally present in many foods, and is a cofactor in more than 300 enzyme systems that regulate many biochemical reactions in the body (Rude 2012; Volpe 2012), as well as energy production, oxidative phosphorylation and glycolysis, as well as transportation of calcium and potassium ions across cell 
membranes (Volpe 2012). Mild deficiency of magnesium may lead to loss of appetite, nausea, vomiting, fatigue, and weakness, while severe deficiency leads to tingling, numbness, muscle contractions and cramps, seizures, poor bone growth, joints pains, fertility problems, abnormal heart rhythms and coronary spasms can occur (Rude 2012; Emmanuel et al., 2018). The results from the present study show a range between $76.49 \mu \mathrm{g} / \mathrm{g}$ (Dawakin Kudu honey) to $78.83 \mu \mathrm{g} / \mathrm{g}$ (Makoda honey) for the pure honey samples analyzed, and this agrees with similar result by Boussaid et al., (2018) who reported a range of 74.90 to 78.12 $\mu \mathrm{g} / \mathrm{g}$ for six honey samples from Tunusia. Other results similar to this study were reported by Fernandez-Torres et al., (2005); Pisani et al., (2008); Chua et al., (2012); Mohammed et al., (2014); Vanhanen et al., (2011); Bontempo et al., (2017); Altunatmaz et al., (2018). Lower magnesium concentrations in honey samples were however reported by Liberato et al., (2012); Adeniyi et al., (2014); Ndife et al., (2014); Ahed and Khalid (2017); Nwoko et al., (2017).

Zinc is a trace element that is necessary for a healthy immune system, with its deficiency making a person more susceptible to disease and illness (Haase and Schomburg 2019). Zinc has many functions in the human body. It helps in stimulating the activities of many different enzymes in the body, plays a role in wound healing, and in the treatment to diarrhea (Mason 2016; Salwen 2017). In this study, a range of $31.15 \mu \mathrm{g} / \mathrm{g}$ (Ungogo honey) to $48.92 \mu \mathrm{g} / \mathrm{g}$ (Makoda honey) was reported for zinc in the six pure honey samples analyzes, and these results are within the 1.734 to $245.205 \mu \mathrm{g} / \mathrm{g}$ range reported by Altunatmaz et al., (2018) for 65 honey varieties produced in Turkey. The results of this study also agree with that reported by Bartha et al., (2020) who reported a range of 15.00 to $36.40 \mu \mathrm{g} / \mathrm{g}$ for some honey samples from Romania. The results from this study are also close to that reported by Celechovska and Vorlova (2001); Tuzen and Soylak (2005); Gulfraz et al., (2010); Mohammed et al., (2014); Ezeh et al., (2018); Adugna et al., (2020). However, the results from this study are found to be much higher than that reported by other researchers (Turhan, 2007; Tuzen et al., 2007; Kolayli et al., 2008; Kumar et al., 2013; Mohammed et al., 2014; Aghamirlou et al., 2015; Sireli et al., 2015; Nwoko et al., 2017). While Oyeyemi et al., (2015) reported a value of $124.24 \mu \mathrm{g} / \mathrm{g}$, which is much higher than that of this study. The 33.37 to 48.92 $\mu \mathrm{g} / \mathrm{g}$ range reported in this study is below the maximum permissible limit $(350 \mu \mathrm{g} / \mathrm{g})$ recommended by Codex Alimentarius Commission (2002).

Iron is an essential nutrient mineral that serves several important functions, but its main function is to carry oxygen throughout our bodies and making red blood cells (Beard and Dawson 1997). Iron is an essential element for almost all living organisms as it participates in a wide variety of metabolic processes, including deoxyribonucleic acid (DNA) synthesis and electron transport (Abbaspour et al., 2014). Iron deficiency occurs when the body does not have enough of the mineral iron, and this leads to abnormally low levels of red blood cells (Haas and Brownlie, 2001). The concentration of iron in the six honey samples analyzed in this study was found to be between 6.84 $\mu \mathrm{g} / \mathrm{g}$ (Dawakin Kudu honey) to $14.27 \mu \mathrm{g} / \mathrm{g}$ (Ajingi honey) range, and this result compares with similar results reported by Nanda et al., (2003); Adebiyi et al., (2004); Atrouse et al., (2004); Terrab et al., (2005); Yarsan et al., (2007); Pisani et al., (2008); Ahed and Khalil (2012); Liberato et al., (2012); Kumar et al., (2013) and Altunatmaz et al., (2018). However, the results from study was found to be much lower than that reported by Mohammed et al., (2014) who reported a very high iron content of $162.31 \mu \mathrm{g} / \mathrm{g}$; and that reported by Oyeyemi et al., (2015) who reported a value of $171.52 \mu \mathrm{g} / \mathrm{g}$ for honey samples collected from Ekiti State, Nigeria. While on another hand, the results of this are much higher than that reported by Adeniyi et al., (2014); Maiyo et al., (2014); Ndife et al., (2014) and Boussaid et al., (2018).

Manganese is required for enzyme functioning in the body, wound healing, prevention of anemia, nutrient absorption, alleviating premenstrual syndrome, bone development and antioxidant protection, with its deficiency resulting in poor bone growth, joints pains and fertility problems (Emmanuel et al., (2018). However, when exposed for a very long time, manganese causes impotency in men and also Parkinson disease (Emmanuel et al., (2018), as such honey should not contain high concentration on manganese. The concentrations of manganese in the six pure honey samples were found to be between 0.08 $\mu \mathrm{g} / \mathrm{g}$ (Dawakin Kudu honey) to $0.13 \mu \mathrm{g} / \mathrm{g}$ (Makoda honey) range, and these results are far below the FAO/WHO maximum permissible limit of $5.50 \mu \mathrm{g} / \mathrm{g}$. The findings in this study compare with similar results from other researchers (FernandezTorres et al., 2005; Fredes and Montenegro 2006; Belouali et al., 2008; Liberato et al., 2013; Doker et al., 2014; Czipa et al., 2015; Oroian et al., 2016; Ahed and Khalid 2017; Bilandzic et al., 2017; K1lic et al., 2017; Altunatmaz et al., 2018. The results from the present study are however much lower than those reported by Rasheed and Soltan (2004); Golob et al., (2005); Turhan (2007); Tuzen et al., (2007); Kolayli et al., (2008); Chua et al., (2012); Bontempo et al., (2017). High levels of manganese in some honey samples may be attributed to its presence in the dust through the air, surface waters, burning of fossil fuels and industrial activities (Emmanuel et al., (2018).

Copper is one of the essential trace minerals necessary for survival, and is found in almost all the body tissues, playing a role in maintaining nerve cells and the immune system, as well as in making red blood cells and (Megan 2017). It is also believed to play a major role in the formation collagen, helps in iron absorption and in the production of body energy, with too much and too little copper reported to affect how the brain works (Megan 2017). The concentration of copper in the present study was found to be between the range of $0.12 \mu \mathrm{g} / \mathrm{g}$ (Gwarzo honey) to $0.25 \mu \mathrm{g} / \mathrm{g}$ (Ajingi honey), and this compares with similar results reported by Celechovska and Vorlova (2001); Devillers et al., (2002); Tuzen and Soylak (2005); Akbari et al., (2012); Derebasi et al., (2014), while some researchers (Roman et al., 2011; Dzugan et al., 2017) have reported much higher concentrations. The concentrations of copper in the six pure honey samples analysed in this study were found to be far below the FAO/WHO maximum permissible limit of $300 \mu \mathrm{g} / \mathrm{g}$.

Nickel is an essential trace element for both human and animal health (Zaigham et al., 2012) that is required in small doses, but can be harzardous at very high doses (Sreekanth et al., 2013). The carcinogenic effect of nickel at higher doses has been reported to cause cancer of the larynx, nose, lungs and prostate, as well as birth defect, lung embolism, respiratory failure, asthma and bronchitis (Zaigham et al., 2012; Guodong et al., 2017). The concentrations of nickel analyzed in this study were 
found to be between the range of $0.98 \mu \mathrm{g} / \mathrm{g}$ (Dawakin Kudu honey) to $1.27 \mu \mathrm{g} / \mathrm{g}$ (Ungogo honey), and all these results are far below the WHO/FAO maximum permissible limit for nickel (5.0 $\mu \mathrm{g} / \mathrm{g}$ ). The results of this study also fall within the range of 0.39 $8.60 \mu \mathrm{g} / \mathrm{g}$ reported by Ahed and Khalid (2017), with Aghamirlou et al., (2015) also reporting the mean concentration of nickel for honey samples from Iran as $0.91 \mu \mathrm{g} / \mathrm{g}$. The results from the present study are a little higher than $0.480 \mu \mathrm{g} / \mathrm{g}$ reported by Sobhanardakani and Kianpour (2016) for honey samples collected in Turkey. However, the results are lower than that reported by Emmanuel et al., (2018) who reported the mean concentration of nickel in some honey samples to be between the range of 1.200 to $44.100 \mu \mathrm{g} / \mathrm{g}$. Presence of nickel in honey might not be as significant as other metals because some honey samples have been reported to contain non-detectable amount of nickel (Adugna et al., 2020).

Lead is a non-essential metal with no physiological role in both plants and animals (Bartha et al., 2020), with its exposure occurring through contacts with water, air, soil and contaminated food (Kabata-Pendias 2010; Bartha et al., 2020). Exposure to lead causes neurological effects, renal tubular dysfunction, anemia, nephropathy, as well as impairment of reproductive functions (HPA 2016; Bartha et al., 2020). Accumulation of lead in the environment mainly occurs as a result of melting and production of metals, mining, as well as its release from some industries like the battery industry (Bartha $e t$ al., 2020). In this study, three of the six honey samples analyzed (Ajingi, Gwarzo and Makoda honeys) recorded a non-detectable concentration of lead, while the other three recorded a range of $0.0001 \mu \mathrm{g} / \mathrm{g}$ (Ungogo and Bebeji honeys) to $0.0002 \mu \mathrm{g} / \mathrm{g}$ (Dawakin Kudu honey). The results from this study partially agree with similar results by Okeola et al., (2020) who reported a non-detectable concentration of lead in all the analyzed honey samples collected from Ilorin Kwara state, Nigeria, with Nascimento et al., (2015) also reporting similar results However, the results from this study are found to be much lower than that reported by other researchers (Maiyo et al., 2014; Aghamirlou et al., 2015; Altunatmaz et al., 2018). The concentrations of lead in the six pure honey samples analysed in this study were found to be far below the FAO/WHO maximum permissible limit of $0.50 \mu \mathrm{g} / \mathrm{g}$.

\section{CONCLUSION}

The six honey samples were collected from the three Senatorial Districts of Kano state, Nigeria, and were subjected to mineral contents analysis. Metals (K, Na, Ca, Mg, Zn, Fe, Mn, Cu, Ni and $\mathrm{Pb}$ ) concentrations were determined, and the values were found to be below the WHO/FAO recommendations. However, there are some little variations between the results of the three Senatorial Districts, with such variations attributed to plant source of the nectar, geographical factors, and nearness of the honey bee source, as well as soil composition and collection techniques.

\section{REFERENCES}

Abbaspour N., Hurrell R. and Kelishadi R. (2014): Review on Iron and its Importance for Human Health. Journal of Research in Medical Sciences 19(2):164-74.

Abel AA. and Adedoyin DB. (2011): Physico-Chemical Evaluation of the Authenticity of Honey Marketed in
Southwestern Nigeria, Journal of Basic and Applied Scientific Research 1(12):3339-3344.

Aburto NJ., Hanson S., Gutierrez H., Hooper L., Elliott P. and Cappuccio FP. (2013): Effect of Increased Potassium Intake on Cardiovascular Risk Factors and Disease: Systematic Review and Meta-Analyses British Medical Journal 3:346.

Adebiyi FM., Akpan I., Obiajunwa EI. and Olaniyi HB. (2004): Chemical/Physical Characterization of Nigerian Honey. Pakistan Journal of Nutrition 3(5):278-281.

Adeniyi KA., Daudu OAY., Abubakar A., Ismail AD., Busari MB., Abdulsalami H. and Oyibo-Usman K A. (2014): Comprative Analysis of the Proximate and Nutritional Compositions of Nigerian Bitter and Sweet Honey from Apis mellifera, International Journal of Scientific and Research Publications, 4(11):1-4.

Adugna E., Ariaya H., Gebremariam B. and Ayenew A. (2020): Determination of some Heavy Metals in Honey from Different Regions of Ethiopia, Cogent Food and Agriculture, 6:1-14.

Agbagwa OE., Otokunefor TV. and Frank-Peterside N. (2011): Quality Assessment of Nigeria Honey and Manuka Honey. Journal of Microbiology Research, 1(3):20-31.

Aghamirlou HM., Khadem M., Rahmani A., Sadeghian M., Mahvi AH., Akbarzadeh A. and Nazmara S. (2015): Heavy metals Determination in Honey Samples using Inductively Coupled Plasma-Optical Emission Spectrometry, Journal of Environmental Health 13(39):1-8.

Ahed A. and Khalid MS. (2017): Physico-Chemical Properties of Multi-Floral Honey from the West Bank, Palestine, International Journal of Food Properties, 20(2):447-454.

Ajlouni S. and Sujirapinyokul P. (2010): Hydroxymethylfurfuraldehyde and Amylase Contents in Australian Honey. Food Chemistry, 119(3):1000-1005.

Akbari B., Gharanfoli F., Khayyat MH., Khashyarmanesh Z., Rezaee R. and Karimi G. (2012): Determination of heavy metals in different honey brands from Iranian markets, Food Additives and Contaminants, Part B:1-7.

Al ML., Daniel D., Moise A., Bobis O., Laslo L. and Bogdanov S. (2009): Physico-Chemical and Bioactive Properties of Different Floral Origin Honeys from Romania. Food Chemistry, 112:863-867.

Altunatmaz SS., Tarhan D., Aksu F., Ozsobaci NP2, Or EM., Barutçu UB. (2018): Levels of Chromium, Copper, Iron, Magnesium, Manganese, Selenium, Zinc, Cadmium, Lead and Aluminium of honey varieties produced in Turkey, Food Science and Technology Compinas 39(2):1-6.

Atrouse OM., Oran SA. and Al-Abbadi SY. (2004): Chemical 
Analysis and Identification of Pollen Grains from Different Jordanian Honey Samples. International Journal of Food Science and Technology, 39(4):1-5.

Bartha S., Taut I., Goji G., Vlad IA. Dinulica F. (2020): Heavy Metal Content in PolyfloralHoney and Potential Health Risk. A Case Study of Cops, a Mica, Romania International Journal of Environmental Research and Public Health 17:2-12.

Beard JL. and Dawson HO. (1997): Iron, in: O'Dell BL. Sunder RA Editors Handbook of Nutritionally Essential Mineral Elements, New York, CRC Press. Pp. 275-334.

Belouali H., Bouaka M. and Hakkou A. (2008): Determination of some Major and Minor Elements in the East of Morocco Honeys through Inductively Coupled Plasma Optical Emission Spectrometry. Apiacta, 43:17-24.

Bilandzic, N., Tlak Gajger I., Kosanovic M., Calopek B., Sedak M., Solomun Kolanovic B., Varenina I., Luburic DB., Varga I. and Dokic M. (2017): Essential and Toxic Element Concentrations in Monofloral Honeys from Southern Croatia. Food Chemistry, 234:245-253.

Bogdanov S. (2009): Honey Composition. In: Book of Honey, Chapter 5. Bee Product Science. Pp. 1-10.

Bontempo L., Camin F., Ziller L., Perini M., Nicolini G. and Larcher R. (2017): Isotopic and Elemental Composition of Selected Types of Italian Honey. Measurement, 98:283-289.

Boussaid A., Chouaibia M., Rezigb L., Hellalc R., Donsìa F., Ferraria G. and Hamdib S. (2018): Physicochemical and Bioactive Properties of Six Honey Samples from Various Floral Origins from Tunisia. Arabian Journal of Chemistry, 11(2):265274.

Celechovska O. and Vorlova L. (2001): Groups of HoneyPhysicochemical Properties and Heavy Metals. Acta. Veterinaria Brno. 70:91-95.

Chua LS., Abdul-Rahaman NL., Sarmidi MR. and Aziz R. (2012): Multi-Elemental Composition and Physical Properties of Honey Samples from Malaysia. Food Chemistry, 135(3):880 887.

Codex Alimentarius Commission Standards. (2002): Draft revised standard for honey. 9-11 February 2000. Joint FAO/WHO Food Standards Programme.

Conti ME. (2000): Lazio Region (Central Italy) Honeys: A Survey of Mineral Content and Typical Quality Parameters, Food Control, 11(6):459-463.

Czipa N., Andrasi D. and Kovacs B. (2015): Determination of Essential and Toxic Elements in Hungarian Honeys. Food Chemistry, 175:536-542.
De Rodriguez GO., de Ferrer BS., Ferrer A. and Rodriguez B. (2004): Characterization of Honey Produced in Venezuela. Food Chemistry, 84(4):499-502.

Derebası E., Bulut G., Col M., Guney F., Ya,sar N. and Erturk O. (2014): Physicochemical and Residue Analysis of Honey from Black Sea Region of Turkey. Fresenius Environ. Bull.23:10-17.

Devillers J., Dore JC., VielMarenco CM., Poirier-Duchene F., Galand N., Subirana N. (2002) Typology of French Acacia Honeys Based on their Concentrations in Metallic and Nonmetallic Elements. In Honey Bees: Estimating the Environmental Impact of Chemicals; Devillers J., PhamDelegue MH., Eds. Taylor \& Francis: Oxfordshire, UK, Pp. 248-269.

Doker S., Aydemir O. and Uslu M. (2014): Evaluation of Digestion Procedures for Trace Element Analysis of Cankiri, Turkey Honey by Inductively Coupled Plasma Mass Spectrometry. Analytical Letters, 47(12):2080-2094.

Downey G., Hussey K., Daniel-Kelly J., Walshe TF. and Martin PG. (2005): Preliminary Contribution to the Characterization of Artisanal Honey Produced on the Island of Ireland by Palynological and Physico-Chemical Data, Food Chemistry, 91(2):347-354.

Dzugan M., Zaguła G., Wesołowska M., Sowa P. and Puchalski CZ. (2017): Levels of Toxic and Essential Metals in Varietal Honeys from Podkarpacie. Journal of Elementology, 22:10391048.

El-Bialee NM. and Sorour MA. (2011): Effect of Adulteration on Honey Properties, International Journal of Applied Science and Technology, 1(6):122-133.

Emmanuel KM., Michael D., Eugenia B. and Prince O. (2018): Determination of Heavy Metals and Potential Health Risk Assessment of Honey Harvested from the Tamale Metropolis of Ghana Using Atomic Absorption Spectrophotometer (AAS) Elixir Pollution 121:51522-51525.

Ezeh E., Okeke O., Ozuah AC. and Nwoye B. (2018): Comparative Assessment of the Heavy and Trace Metal Levels in Honey Produced within Nsukka and Enugu Metropolis, Food and Public Health 8(2):42-46.

Farida I., Rashid M., Noor I., Ghulam S, Asif MM. and Hammad S. (2014): Physicochemical Analysis of Honey Samples Collected from Local Markets of Rawalpindi and Islamabad, Pakistan, American Journal of Biochemistry, 4(2):35-40.

Fernandez-Torres R., Perez-Bernal JL., Bello-Lopez MA., Callejon- Mochon M., Jiménez-Sanchez JC. and Guiraum-Perez A. (2005): Mineral Content and Botanical Origin of Spanish Honeys. Talanta, 65(3):686-691. 
Finola MS., Lasagno MC. and Marioli JM. (2007): Microbiological and Chemical Characterization of Honeys from Central Argentina. Food Chemistry, 100(4):1649-1653.

Fredes C. and Montenegro G. (2006): Heavy Metal and other Trace Elements Contents in Honey Bee in Chile. Ciencia e Investigación Agraria 33(1):50-58.

Golob T., Dobersek U., Kump P. and Necemer M. (2005): Determination of Trace and Minor Elements in Slovenian Honey by Total Reflection X-Ray Fluorescence Spectroscopy. Food Chemistry, 91(4):593-600.

Gomes S., Dias LG., Moreira LL., Rodrigues P. and Estevinho L. (2010) Physico-Chemical, Microbiological and Antimicrobial Properties of Commercial Honeys from Portugal. Food Chemistry and Toxicology 48:544-548.

Gulfraz M., Ifftikhar F., Asif S., Raja GK., Asad JM.1, Imran M., Abbasi K. and Zeenat A. (2010): Quality assessment and antimicrobial activity of various honey types of Pakistan, African Journal of Biotechnology 9(41):6902-6906.

Guodong L., Simonne EH. and Yuncong L. (2017): Nickel Nutrition in Plants, UFIFAS Extension 1-6.

Haase H. and Schomburg L. (2019): You'd Better Zinc-Trace Element Homeostasis in Infection and Inflammation, Nutrients, 11(9):1-7.

Haas JD. and Brownlie T (2001): Iron Deficiency and Reduced Work Capacity: A Critical Review of the Research to Determine a causal Relationship. Journal of Nutrition 31(2-2):676-688.

Health Protection Agency HPA (2016): Chemical Hazards Compendium and Health Emergency Planning. Lead: Health E_ects, Incident Management and Toxicology. Lead: Toxicological Overview; GOV.UK: London, UK, Pp. 14.

Hernandez OM., Fraga JMG., Jimenez AI., Jimenez F. and Arias JJ. (2005): Characterization of Honey from the Canary Islands: Determination of the Mineral Content by Atomic Absorption Spectrophotometry. Food Chemistry, 93(3):449-458.

Juszczak L., Socha R., Roznowski J., Fortuna T. and Nalepka K. (2009): Physicochemical Properties and Quality Parameters of Herb Honeys. Food Chemistry, 113:538-542.

Kabata-Pendias A. (2010): Trace Elements in Soils and Plants, 4th ed.; CRC Press: Boca Raton, FL, USA, Pp 223.

Kanu PA., Shifa N., Monica K. and Chanderdeep T. (2013): Nephrolithiasis: Molecular Mechanism of Renal Stone Formation and the Critical Role Played by Modulators, BioMed Research International, 2013:1-21.

Kılıc AS., Dinc H., Paksoy N., Temamogulları FK. and Savrunlu M. (2017): Analyses of Mineral Content and Heavy Metal of
Honey Sample from South and East Region of Turkey by using ICP-MS. International Journal of Analytical Chemistry, (2017):1.6

Kolayli S., Kongur N., Gundogdu A., Kemer B., Duran C. and Aliyazicioglu R. (2008): Mineral Composition of Selected Honeys from Turkey. Asian Journal of Chemistry, 20:24212425.

Kucuk M., Kolaylı S., Karaoglu S., Ulusoy E., Baltacı C. and Candan F. (2007): Biological Activities and Chemical Composition of Three Honeys of Different Types from Anatolia. Food Chemistry, 100(2):526-534.

Kujawski MW. and Namiesnik J. (2008): Challenges in Preparing Honey Samples for Chromatographic Determination of Contaminants and Trace Residues. TrAC Trends in Analytical Chemistry, 27(9):785-793.

Kumar HMM., Anand AP., Deepa V. and Siddagangaiah H. (2013): Study of Physicochemical Parameters and Antioxidants in Honey Collected from Different Locations in India, International Journal of Pharmacy and Life Sciences, 4(12):3159-3165.

Laleh M., Mohsen E. and Ali H. (2013): Evaluation of some Physicochemical and Rheological Properties of Iranian Honeys and the Effect of Temperature on its Viscosity. AmericanEurasian Journal of Agricultural and Environmental Sciences, 13(6):807-819.

Liberato MTC., Morais SM., Magalhaes CEC1, Magalhaes IL., Cavalcanti DB., Silva MM. (2012): Physicochemical Properties and Mineral and Protein Content of Honey Samples from Ceara State, Northeastern Brazil, Food Science and. Technology, Campinas, 33(1):38-46.

Maiyo WK., Kituyi JL., Mitei YJ. and Kagwanja SM. (2014): Heavy Metal Contamination in Raw Honey, Soil and Flower Samples Obtained from Baringo and Keiyo Counties, Kenya, International Journal of Emerging Science and Engineering 2(7):5-9.

Mason JB. (2016): Vitamins, Trace Minerals, and other Micronutrients. In: Goldman L, Schafer AI, Eds. Goldman-Cecil Medicine. $25^{\text {th }}$ Ed. Philadelphia, PA: Elsevier Saunders; Pp. 218.

Matusevicius P., Staniskiene B. and Budreckiene R. (2010): Metals and Organochlorine Compounds in Lithuanian Honey. Polish Journal Food and Nutrition Sciences 60:159-163.

Mohammed M., Muhammed AZC., Mohammad AR., Sulaiman SA. and Gan SH. (2014): Determination of Mineral, Trace Element, and Pesticide Levels in Honey Samples Originating from Different Regions of Malaysia Compared to Manuka Honey, BioMed Research International (2014):1-10.

Nanda V., Sarkar BC., Sharma HK. and Bawa AS. (2003): 
Physico-Chemical Properties and Estimation of Mineral Content in Honey Produced from Different Plants in Northern India Journal of Food Composition and Analysis, 16(5):613-619.

Nascimento AS., Marchini LC., Carvalho CAL., Araujo DFD., Silveira TA. and Olinda RA. (2015). Determining the Levels of Trace Elements $\mathrm{Cd}, \mathrm{Cu}, \mathrm{Pb}$ and $\mathrm{Zn}$ in Honey of Stingless Bee (Hymenoptera: Apidae) Using Voltammetry. Food and Nutrition Sciences, 6(07):591-596.

Ndife J., Abioye L. and Dandago M. (2014): Quality Assessment of Nigerian Honey Sourced from Different Floral Locations, Nigerian Food Journal, 32(2):48-55.

Nnam NM. (2003). Evaluation of the nutrient and sensory properties of porridges from African yam bean (Sphenostylis stenocarpa) and maize (Zea mays L.) Flours. Nigeria Research in Education. 9:49-54.

Nwoko CIA., Nkwoada AU., Ubeh EO. and Njoku A. (2017): Characterization of Selected Honey in South-East Nigeria: Theoretical Translation, International Journal of Environment Agriculture and Biotechnology 2(2):695-700.

Okeola FO., Oluade O. Liad MT. (2020): Stingless Bee Honey as Bio-Indicator of Heavy Metals Pollution in and around the University of Ilorin Environ Kwara State, Nigeria, Journal of Applied Science and Environmental Management, 24(5):773778.

Omafuvbe BO. and Akanbi OO. (2009): Microbiological and Physico-Chemical Properties of some Commercial Nigerian Honey. African Journal Microbiology Research 3:891-896.

Oroian M., Ropciuc S. and Paduret S. (2018): Honey Authentication using Rheological and Physicochemica Properties. Journal of Food Science and Technology, 55(12):4711-4718.

Oyeyemi SD., Kayode J. and Owolabi MO. (2015): Comparative Nutritional Studies on Honey Samples in Ado Ekiti, Ekiti State, Nigeria. Donnish Journal of Medicinal Plant Research 2(2):16-20.

Pisani A., Protano G. and Riccobono F. (2008): Minor and Trace Elements in Different Honey Types Produced in Siena County (Italy), Food Chemistry, 107(4):1553-1560.

Piste P., Didwagh S. and Mokashi A. (2013): Calcium and its Role in Human Body, International Journal of Research in Pharmaceutical and Biomedical Sciences 4(2):659-668.

Pohl P. (2009): Determination of Metal Content in Honey by Atomic Absorption and Emission Spectrometries. Trends in Analytical Chemistry, 28:117-128.

Raman R. (2017): What Does Potassium Do for Your Body? A Detailed Review, Healthline Media a Red Ventures Company.
Rasheed M. and Soltan M. (2004): Major and Trace Elements of 111 Different Types of Egyptian Mono-Floral and Non-Floral Bee Honeys. Journal of Food Composition and Analysis, 17(6):725-735.

Rodriguez GO., Ferrer BS., Ferrer A. and Rodriguez B. (2004): Characterization of Honey Produced in Venezuela. Food Chemistry, 84:499-502.

Roman A., Majewska BM. and Popiela-Pleban E. (2011): Comparative Study of Selected Toxic Elements in Propolis and honey. Journal of Apicultural Science 55:97-105.

Rude RK. (2012): Magnesium. In: Ross AC, Caballero B, Cousins RJ, Tucker KL, Ziegler TR, eds. Modern Nutrition in Health and Disease. $11^{\text {th }}$ Ed. Baltimore, Mass: Lippincott Williams and Wilkins; Pp. 159-175.

Saeed A., Javid A., Bilal J., Said H., Sudhair A. and Muhammad S. (2014): Comparative Physiochemical Analysis of Imported and Locally Produced Khyber Pakhtunkhwa Honey Global Journal of Biotechnology and Biochemistry 9(3):55-59.

Salwen MJ. (2017): Vitamins and Trace Elements. In: McPherson RA, Pincus MR, eds. Henry's Clinical Diagnosis and Management by Laboratory Methods. $23^{\text {rd }}$ Ed. St Louis, MO: Elsevier; Pp. 426.

Saxena S., Gautam S. and Sharma A. (2010): Physical, Biochemical and Antioxidant Properties of Some Indian Honeys. Food Chemistry 118(2):391-397.

Sireli UT., Iplikcioglu CG., Yurdakok DB., Filazi A. and Ulker H. (2015): Detection of Metals in Different Honey Brands. Kafkas Üniversitesi Veteriner Fakültesi Dergisi, 21(6):915-918.

Sobhanardakani S. and Kianpour M. (2016): Heavy Metal Levels and Potential Health Risk Assessment in Honey Consumed in the West of Iran. Avicenna Journal of Environmental Health Engineering, 3(2):77-95.

Sreekanth TVM., Nagajyothi PC., Lee T.N. and Prasad KV. (2013): Occurrence, Physiological Responses and Toxicity of Nickel in Plants. International Journal of Environmental Science and Technology, 10(5):1129-1140.

Standing Committee on Nutrition (2006): The double burden of malnutrition - A challenge for cities worldwide, Third World Urban Forum - Vancouver 19-23 June 2006 SCN Statement.

Terrab A., Recamales AF., Gonzalez-Miret ML. and Heredia FJ. (2005): Contribution to the Study of Avocado Honeys by their Mineral Contents using Inductively Coupled Plasma Optical Emission Spectrometry, Food Chemistry, 92(2):305-309.

Turan M., Kordali S., Zengin H., Dursun A. and Sezen Y. (2003): Macro and Micro Mineral Content of some Wild Edible Leaves Consumed in Eastern Anatolia, Acta Agriculturae Scandinavica, 
Section B-Soil and Plant Science, 53(3):129-137.

Turhan K. (2007). Chemical Contents and some Trace Metals of Honeys Produced in the Middle Anatolia Region of Turkey. Fresenius Environmental Bulletin, 16(5):460-465.

Tuzen M. and Soylak M. (2005): Trace Heavy Metal Levels in Microwave Digested Honey Samples from Middle Anatolia, Turkey. Journal of Food and Drug Analysis 13:343-347.

Tuzen M., Silici S., Mendil D. and Soylak, M. (2007): Trace Element Levels in Honeys from Different Regions of Turkey. Food Chemistry, 103(2):325-330.

Vanhanen LP., Emmertz A. and Savage GP. (2011): Mineral Analysis of Mono-Floral New Zealand Honey. Food Chemistry 128:236-240.
Volpe SL. (2012): Magnesium. In: Erdman JW, Macdonald IA, Zeisel SH, eds. Present Knowledge in Nutrition. $10^{\text {th }}$ Ed. Ames, Iowa; John Wiley \& Sons, Pp. 459-474.

Wang J. and Li QX. (2011): Chemical Composition, Characterization and Differentiation of Honey Botanical and Geographical Origins. In S. Taylor (Ed.), Advances in Food and Nutrition Research 62:89-137.

Yarsan E., Karacal F., Ibrahim IG., Dikmen B., Koksal A. and Das YK. (2007): Contents of Some Metals in Honeys from Different Regions in Turkey. Bulletin of Environmental Contamination and Toxicology 79(3):255-258.

Zaigham H., Zubair A., Khalid UK., Mazhar I., Rizwan UK., Jabar ZKK. (2012): Civic Pollution and its Effect on Water Quality of River Toi at District Kohat, NWFP, Research Journal of Environmental and Earth Sciences, 4(3):334-339. 